\title{
Effects of Soil-Applied and Trunk and Petiole-Injected Manganese on Manganese Content of Coconut Palm (Cocos nucifera)
}

\author{
Timothy K. Broschat and Joseph J. Doccola
}

\begin{abstract}
Manganese deficiency is a common and potentially fatal disorder of palms growing in highly leached and calcareous soils. Soil applications of $\mathrm{MnSO}_{4}$ may not always be effective in treating this disorder due to rapid oxidation of $\mathrm{Mn}$ to less available forms. Trunk injection with $\mathrm{MnSO}_{4}(2.0 \mathrm{~g} \mathrm{Mn})$ was found to be more effective in increasing foliar Mn concentrations than soil application (192 g Mn) or petiole injections with $0.1 \mathrm{~g} \mathrm{Mn}$ in a single hole, or $0.5 \mathrm{~g}$ Mn divided among four holes. In contrast to trunk injection, neither petiole injections nor soil application of $\mathrm{MnSO}_{4}$ increased foliar $\mathrm{Mn}$ concentrations above that of the untreated control palms. Trunk injections, while effective, result in permanent wounds that could potentially serve as entry sites for the trunk pathogen Thielaviopsis paradoxa, especially on young palms with minimal trunks.

Key Words. Fertilization; Palm; Manganese Deficiency; Manganese Sulfate; Micronutrients.
\end{abstract}

Manganese deficiency is a common and potentially fatal disorder of palms growing in highly leached sand and calcareous soils (Elliott et al. 2004). Soil applications of manganese sulfate are usually effective in correcting these deficiencies, but in the calcareous soils of southern Florida, U.S., massive amounts of this product are required due to their high $\mathrm{pH}$ and buffering capacity (Dickey 1977). While foliar sprays with manganese sulfate are an effective means of increasing Mn concentrations within palm leaves (Dickey 1977; Broschat 1991), this method is impractical for large specimen palms and must be repeated several times per year.

In dicot trees, trunk injections with soluble nutrients are often employed to alleviate deficiencies of $\mathrm{Mn}$ or Fe in trees with impaired root systems or those growing in calcareous soils. The wounds caused by these injections are eventually walled off with callous tissue produced by the vascular cambium so that no permanent visible damage is done to the trunk. Palms, however, do not have a vascular cambium and are incapable of walling off wounds in the trunk (Tomlinson 1990). Thus, wounds from trunk injections of palms are permanent, unsightly, and can become potential entry sites for trunk pathogens such as Thielaviopsis paradoxa which require trunk wounds for infection to occur (Elliott et al. 2004). Trunk injections are therefore normally reserved for treatment or prevention of lethal diseases or disorders where soil or foliar applications are ineffective or impractical.

A possible alternative injection site for palms is the leaf petiole which can be quite large in many palm species. McCoy (1977) demonstrated that oxytetracycline (OTC) injected into coconut palm (Cocos nucifera) petioles was translocated to other leaves within the canopy in sufficient concentrations to control lethal yellowing disease. Petiole injections have the advantage of causing wounds only to tissue that will eventually be shed by the palm and thus no permanent wounds to the trunk are created. On the other hand, petiole injection may require multiple injection sites in order to introduce sufficient volumes of the solution, and in tall specimens, accessing the palm leaves for treatment requires special equipment. The purpose of this study was to compare the relative effectiveness of manganese sulfate in increasing foliar Mn concentrations when applied to the soil or injected into the trunk or petioles of palms.

\section{MATERIALS AND METHODS}

A 29-year-old planting of Fiji Dwarf coconut palms with trunk heights of 3-4.5 m was used for this study. The plot was located in Davie, FL, U.S. (latitude 26 4' $56^{\prime \prime} \mathrm{N}$, longitude $80^{\circ} 14^{\prime} 23^{\prime \prime} \mathrm{W}$ ) and had a Margate Fine Sand soil with a $\mathrm{pH}$ of 6.1 and cation exchange capacity of $3.1 \mathrm{meq} / 100 \mathrm{~g}$. The ground cover was a very sparse cover of weeds due to shading by the palms and thus competition by groundcovers for Mn was not likely to be a significant factor. None of the palms exhibited symptoms of Mn deficiency at any time during the experiment. Ten replicate trees spaced $5 \mathrm{~m}$ apart were randomly assigned to each of the following treatments: (1) Control—no Mn treatment; (2) $600 \mathrm{~g}$ of $\mathrm{MnSO}_{4}$ (=192 g Mn) (TecMangam ${ }^{\circledR}$, Industrias Sulfamex, Tampico, Mexico) broadcast to the soil surface under the canopy; (3) $10 \mathrm{~mL}$ of a $5 \% \mathrm{Mn}$ solution from $\mathrm{MnSO}_{4}(=0.5 \mathrm{~g} \mathrm{Mn}$ ) (Arborjet, Inc., Woburn, MA, U.S.) injected into the petiole bases of four older leaves by drilling holes $7 \mathrm{~mm}$ in diameter by $50 \mathrm{~mm}$ deep, tapping in \#3 Arborplugs $^{\circledast}$ (Arborjet, Inc.), and injecting $2.5 \mathrm{~mL}$ of the solution per leaf using a Quick-jet ${ }^{\circledR}$ microinjector (Arborjet, Inc.); (4) $2 \mathrm{~mL}$ of a $5 \% \mathrm{Mn}$ solution from $\mathrm{MnSO}_{4}(=0.1 \mathrm{~g} \mathrm{Mn})$ injected into a single older petiole as in treatment 3; and (5) $40 \mathrm{~mL}$ of a 5\% Mn solution from $\mathrm{MnSO}_{4}(=2.0 \mathrm{~g} \mathrm{Mn})$ were injected into the trunk about $60 \mathrm{~cm}$ above the ground. The single $7 \mathrm{~mm}$-diameter hole extended into 
the trunk about one-third of its diameter and was injected using the same techniques as treatments 3 and 4 . Arborplugs are polypropylene inserts with a membrane sealing the small-diameter injection port in the center. They are tapped into holes in the trunk such that the membrane is within the central cylinder of the palm trunk containing the vascular bundles. The Quick-jet microinjector is a repeating syringe with a needle that penetrates the Arborplug membrane and injects a measured volume of solution into the trunk or petiole. All treatments were applied April 7-8, 2009.

Prior to treatment, leaf samples consisting of two central leaflets from the youngest fully-expanded leaf (leaf \#1) on each tree were harvested for baseline Mn determinations. Similar samples were collected from the current youngest fully-expanded leaves at 1,3 , and 6 months following treatment. Leaf samples were dried at $60^{\circ} \mathrm{C}$, ground, and digested using a nitric acid-hydrogen peroxide method (United States EPA 1996). Digested samples were analyzed for $\mathrm{Mn}$ concentrations using atomic absorption spectrometry. In order to eliminate intra-plant variation in Mn content, initial Mn concentration data from each tree were subtracted from the 1, 3, and 6-month leaf Mn concentrations. Analysis of variance, with mean separation by the WallerDuncan k-ratio method (SAS Inst., Cary, NC, U.S.), was used to compare changes in $\mathrm{Mn}$ concentrations among treatments.

\section{RESULTS AND DISCUSSION}

Injection of the trunks of coconut palms was relatively simple and leakage was minimal if the Arborplug was properly seated. Injection into petioles was more difficult and the limited capacity of the petiole to absorb injected solutions limited the volumes that could be injected to about $2 \mathrm{~mL}$ per hole. In two of the trunk-injected palms, more than $25 \mathrm{~mL}$ of solution were unable to be injected into a single hole.

Analysis of baseline Mn concentrations showed that all palms were above the $40 \mathrm{ppm}$ threshold for Mn sufficiency (Elliott et al. 2004). However, there was a wide range in concentrations among replicate trees within each treatment. For that reason, the concentrations at 1,3 , and 6 months were subtracted from the initial concentrations to show changes in concentrations over time in response to the various treatments. Treatment 5 (trunk injection) went from the lowest concentration at month 0 to the highest at month 1, and showed an increase in Mn of about 102 ppm (Table 1). Other treatments showed little or no increase in Mn concentrations. At month 3, trunk-injected palms (treatment 5) still had Mn concentrations 113 ppm higher than before treatment while the other four treatments showed net losses in $\mathrm{Mn}$ in their foliage. After 6 months, treatment 5 still had higher Mn concentrations than before treatment, while the other four treatments showed significant drops in Mn concentrations.

The drop in most Mn concentrations over time was most likely due to a dilution effect caused by an increased growth rate during the warm rainy summer months. Broschat (1991) showed a similar drop in Mn concentrations in leaves of untreated pygmy date palms (Phoenix roebelenii) sampled in July, compared to cooler and drier months of February through May at a nearby site. Thus, it was important that changes in Mn concentrations were presented, as opposed to the actual concentrations.

These data suggest petiole injection of older leaves is not an effective method of increasing $\mathrm{Mn}$ in the newest leaf (leaf \#1) of a palm, the site where Mn deficiency develops and the leaf that was sampled in this study. Although injections of the antibiotic OTC into coconut palm petioles provided sufficient chemical in all leaves of the canopy to suppress the lethal yellowing phytoplasma, the concentrations of OTC in noninjected leaves averaged only about one-tenth of that found in injected leaves (McCoy 1977). OTC is known to be phloem-mobile, while $\mathrm{Mn}$ is considered to be only partially so (Bukovac and Wittwer 1957). Broschat (1997) found that Mn was mobilized from older leaves to leaf \#2 within the canopies of coconut palms, but not to leaf \#1. Thus, even if petiole injection had increased Mn concentrations in leaf 2, this would have no effect on the incidence or severity of Mn deficiency, which develops in the expanding leaf 0 and the newly expanded leaf 1 .

In this experiment, soil applications provided a minimal increase in $\mathrm{Mn}$ concentrations at 1 month, but not thereafter, suggesting that applied Mn was quickly oxidized by Mnoxidizing bacteria (Sparrow and Uren 1987). Since the $\mathrm{pH}$ of this soil was not particularly high (6.1), precipitation of $\mathrm{Mn}$ by high soil $\mathrm{pH}$ (Lindsay 1972) was probably less of a factor in this study. Soil applications of $\mathrm{MnSO}_{4}$ were highly effective in increasing $\mathrm{Mn}$ concentrations in the foliage of pygmy date palms growing in a similar soil (Broschat 1991)

\section{CONCLUSIONS}

Petiole injection of Mn is an ineffective means of increasing Mn in leaf \#1 and does not justify the extra effort required to treat palms. On the other hand, in this experiment, trunk injection was more effective than soil application of $\mathrm{MnSO}_{4}$, used much less material, and lasted 6 months. However, because this method results in permanent trunk wounds that could provide entry sites for the lethal trunk pathogen Thielaviopsis paradoxa, this method should not be used on relatively young specimens where foliar sprays are possible and where drilling will necessarily be done into trunk tissue that has not had sufficient time to thoroughly lignify (Tomlinson 1990). Thielaviopsis paradoxa requires a wound for infection

Table 1. Actual and changes in Mn concentrations (from month 0 ) in leaf 1 of coconut palms that were treated with manganese sulfate via soil application, petiole injection, or trunk injection. Means with different letters following are statistically different at the $P=0.05$ level based on the Waller-Duncan k-ratio method. $(n=10)$

\begin{tabular}{|c|c|c|c|c|c|c|c|}
\hline \multirow[t]{2}{*}{ Treatment } & \multicolumn{4}{|c|}{ Actual Mn concentration (ppm) } & \multicolumn{3}{|c|}{ Change in Mn concentration (ppm) } \\
\hline & Month 0 & Month 1 & Month 3 & Month 6 & Month 1 & Month 3 & Month 6 \\
\hline 1: Control (no Mn) & 118.5 & $116.4 \mathrm{~b}$ & $89.8 \mathrm{~b}$ & $69.6 \mathrm{~b}$ & $2.1 \mathrm{~b}$ & $-28.7 b$ & $-48.9 b$ \\
\hline 2: Soil application & 128.6 & $145.7 \mathrm{ab}$ & $97.5 \mathrm{~b}$ & $73.4 \mathrm{~b}$ & $17.2 \mathrm{~b}$ & $-31.1 b$ & $-53.2 b$ \\
\hline 3: Petiole injections (4) & 143.1 & $145.9 \mathrm{ab}$ & $125.6 \mathrm{~b}$ & $86.6 \mathrm{ab}$ & $2.8 \mathrm{~b}$ & $-17.5 b$ & $-56.5 b$ \\
\hline 4: Petiole injection (1) & 112.6 & $110.5 \mathrm{~b}$ & $84.9 \mathrm{~b}$ & $63.6 \mathrm{~b}$ & $-2.1 b$ & $-27.7 b$ & $-49.0 b$ \\
\hline 5: Trunk injection & 89.8 & $191.8 \mathrm{a}$ & $203.2 \mathrm{a}$ & $113.3 \mathrm{a}$ & $101.9 \mathrm{a}$ & $113.4 \mathrm{a}$ & $23.5 \mathrm{a}$ \\
\hline $\mathrm{P}$-value & 0.088 & 0.0254 & 0.0002 & 0.033 & $<0.0001$ & $<0.0001$ & $<0.0001$ \\
\hline
\end{tabular}


and nonlignified tissue is more susceptible than lignified tissue (Elliott et al. 2004). Even on older palms, trunk injection of Mn should not be used unless the palm is suffering from severe Mn deficiency that soil applications have been ineffective in correcting.

Acknowledgments. This research was supported by the Florida Agricultural Experiment Station and by a grant from Arborjet, Inc. The authors wish to thank Susan Thor and William Latham for their assistance in this study.

\section{LITERATURE CITED}

Broschat, T.K. 1991. Effect of manganese source on manganese uptake by pygmy date palms. HortScience 26:1389-1391.

Broschat, T.K. 1997. Nutrient distribution, dynamics, and sampling in coconut and Canary Island date palms. Journal of the American Society for Horticultural Science 122:884-890.

Bukovac, M.J., and S.H. Wittwer. 1957. Absorption and mobility of foliar applied nutrients. Plant Physiology 32:428-435.

Dickey, R.D. 1977. Nutritional deficiencies of woody ornamental plants used in Florida landscapes. University of Florida Agricultural Research Bulletin 791.

Elliott, M.L, T.K. Broschat, J.Y. Uchida, and G.W. Simone (Eds.). 2004. Compendium of ornamental palm diseases and disorders. American Phytopathological Society Press, St. Paul, Minnesota.

Lindsay, W.L. 1972. Inorganic phase equilibria of micronutrients in soils. pp. 41-57. In: J.J Mortvedt, P.M. Giordano, and W.L. Lindsay (Eds.). Micronutrients in agriculture. Soil Science Society of America, Madison, Wisconsin.

McCoy, R.E. 1977. Petiole injection of coconut palm, a method to prevent permanent trunk injury during antibiotic treatment for lethal yellowing. Proceedings of the Florida State Horticultural Society 90:114-117.

Sparrow, L.A., and N.C. Uren. 1987. Oxidation and reduction of Mn in acidic soils: effect of temperature and $\mathrm{pH}$. Soil Biology and Biochemistry 19:143-148.

Tomlinson, P.B. 1990. The structural biology of palms. Clarendon Press, Oxford, UK.

United States Environmental Protection Agency. 1996. Acid digestion of sediments, sludges, and soils. Method 3050B Revision 2.

Timothy K. Broschat (corresponding author)

University of Florida

Fort Lauderdale Research and Education Center

3205 College Avenue

Davie, FL 33314, U.S.

tkbr@ufl.edu

Joseph J. Doccola

Arborjet, Inc.

99 Blueberry Hill Road

Woburn, MA 01801, U.S.

joedoccola@arborjet.com
Résumé. La déficience en manganèse est un désordre courant et potentiellement fatal chez les palmiers poussant dans des sols lessivés et calcaires. Les applications de $\mathrm{MnSO} 4$ dans le sol ne sont pas toujours efficaces pour traiter ce désordre en raison de l'oxydation rapide du Mn vers des formes moins disponibles. L'injection dans le tronc de $\mathrm{MnSO} 4$ (2,0 g de Mn) s'est avéré plus efficace pour accroître les concentrations foliaires en Mn que l'application dans le sol (192 g de Mn) ou les injections par le pétiole avec 1,0 g de Mn par trou individuel ou 0,5 g de $\mathrm{Mn}$ divisé parmi quatre trous. Contrairement à l'injection par le tronc, ni les injections par le pétiole ni l'application dans le sol de MnSO4 n'a permis d'accroître les concentrations foliaires en Mn au-delà du niveau de ceux des palmiers-témoin. Les injections par le tronc, bien qu'efficace, produisaient des blessures permanentes qui pouvaient potentiellement servir de porte d'entrée pour l'agent pathogène du tronc Thielaviopsis paradoxa, particulièrement chez le jeunes palmiers avec des troncs minimaux.

Zusammenfassung. Manganmangel ist ein häufiger und potentiell tödlicher Mangel bei Palmen, die in ausgewaschenen, kalkreichen Böden wachsen. Eine Bodengabe von Mangansulfat ist nicht immer erfolgreich in der Bhandlung, weil Mangan schnell in weniger verfügbare Formen durch Oxidation abgebaut wird. Eine Stamminjektion mit Mangansulfat erwies sich als effektiver, um den Mangangehalt in den Blättern zu erhöhen, als Bodeninjektionen oder Petiolinjektionen mit $0,1 \mathrm{~g}$ Mn in ein Loch oder 0,5 g Mn, aufgeteilt auf vier Löcher. Im Gegensatz zur Stamminjektion konnte weder die Petiolinjektion noch die Bodengabe von Mangansulfat die Mangankonzentration in den Blättern über die Menge der unbehandelten Kontrolle bringen. Die Stamminjektionen, führen trotz ihrer Effektivität zu permanenten Wunden, die potentielle Eintrittspforten für den Krankheitserreger Thielaviopsis paradoxa sind, besonders bei jungen Palmen mit schmalen Stämmen.

Resumen. La deficiencia de manganeso es un desorden común y potencialmente fatal de las palmeras que crecen en suelos lechosos y altamente calcáreos. Las aplicaciones de $\mathrm{MnSO} 4$ no siempre son efectivas para tratar estos desórdenes debido a la rápida oxidación de Mn a formas menos disponibles. Las inyecciones del tronco con MnSO4 (2.0 g Mn) se encontraron más efectivas en incrementar las concentraciones foliares de Mn que las aplicaciones al suelo (192 g Mn) o inyecciones al peciolo con $0.1 \mathrm{~g} \mathrm{Mn}$ en un solo agujero, o $0.5 \mathrm{~g}$ Mn dividido entre cuatro agujeros. En contraste a la inyección al tronco, ni las inyecciones de $\mathrm{MnSO} 4$ al peciolo ni las aplicaciones al suelo incrementaron las concentraciones de $\mathrm{Mn}$ arriba de las palmeras de control no tratadas. Las inyecciones al tronco, aunque son efectivas, resultaron en heridas permanentes que podrían servir potencialmente como sitios de entrada para patógenos del tronco, Thielaviopsis paradoxa, especialmente en palmeras jóvenes con troncos pequeños. 